\title{
Influence Marketing in the Fashion and Beauty Industry
}

\author{
Arminda Paço \& Sofia Oliveira \\ Universidade da Beira Interior \\ E-mail: apaco@ubi.pt / sofiaoliveira098@gmail.com
}

\begin{abstract}
This research aims to identify the importance that influence marketing today plays in fashion and beauty blogs, thus grasping whether these blogs influence the consumer/follower, and simultaneously analysing the motivations that lead followers to consult blogs as well as understanding whether the influence wielded through blogs generates impacts on the attitudes and behaviours in the purchase. A descriptive and quantitative study was developed, with the objective of identifying the importance that influence marketing assumes within the scope of fashion and beauty blogs. To this end, a questionnaire sur-

posed of the followers of the various fashion and beauty blogs. Results point that influence marketing does impact on purchasing intentions as regards the products presented as well as on attitudes and behaviours towards fashion and beauty. Consumers hold favourable opinions towards blogs, irrespective of the age group, with the majority openly accepting that they identify and relate to the bloggers and their blogs. There is a higher frequency of accessing blogs among the older respondents and their motivations to follow these blogs stem from wishing to keep up with the trends and seeking out information.
\end{abstract} vey was carried out with the target audience com-

Keywords: fashion; blogs; influence marketing; bloggers.

\section{Introduction}

7 HE focus on the implementation of effective communications strategies takes on particular importance to organisations operating in the fashion and beauty market, a sector that remains attentive and concerned about the needs of the public and undertaking constant innovation. Correspondingly, consumers are also now increasingly motivated and concerned about their own images, self-esteem and wellbeing, seeking out updated information and opinions about the problems existing in the market.

Hence, we are witnessing the progressive adaptation of the communications strategies deployed by brands and companies, defined according to influence marketing plans in which the

Data de submissão: 2017-09-08. Data de aprovação: 2017-12-04.

A Revista Estudos em Comunicação é financiada por Fundos FEDER através do Programa Operacional Factores de Competitividade - COMPETE e por Fundos Nacionais através da FCT - Fundação para a Ciência e a Tecnologia no âmbito do projeto Comunicação, Filosofia e Humanidades (LabCom.IFP) UID/CCI/00661/2013.
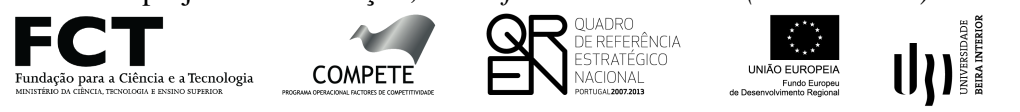

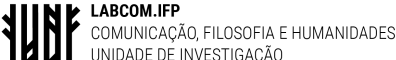
UNIDADE DE INVESTIGACAAO
UNIVERSIDADE DA BEIRA INTERIOR 
focus falls on specific individual targets (opinion leaders), that best adjust to the characteristics of the brand/campaign and that display the capacity to exert influence over potential consumers. According to Taylor and Strutton (2016), social media have contributed to this situation transforming the nature and scope of social networks and allowing users to express their identities. In turn, the companies still increasingly investing in these media (Vries et al., 2012). As Hudson et al. (2015) emphathise, through social media, the marketing professionals can obtain rich and unmediated consumer insights, faster than ever before, and can promote loyalty through networking.

Within this framework, blogs and other communication platforms have emerged that effectively endow a "voice" to individuals on the most varied of themes and also enabling relationships to flourish between the brand-blogger-consumer in which the communication/sharing takes place swiftly and proves able to influence the target public. Blogs have thus become one of the most commonly deployed platforms by influence marketing given that they have the capacity to provide a brand with a channel for conveying the message that it wishes to get recognised.

The main objective of this work is to identify the importance that influence marketing today plays in fashion and beauty blogs, thus grasping whether these blogs influence the consumer/follower simultaneously analysing the motivations that lead followers to consult blogs and the information considered most relevant as well as understanding whether the influence wielded through blogs generates impacts on the attitudes and behaviours in the purchase of fashion and beauty related products.

\section{Literature Review}

\section{Influence Marketing}

Brown and Fiorella (2013) refer to how the marketing of influence, as a strategy, emerged out of a variety of practices and recent studies in which the focus falls on the specific individual targets (or groups of individuals) rather than approaching the overall market as a whole. Influence marketing sets out by identifying those individuals able to wield influence over potential consumers and structuring the subsequent marketing strategies around these influential persons. The authors refer to how the term "influence" still remains both complex and poorly interpreted. This "influence" essentially reflects the "power" generated by a person or entity in relation to (or over) another person.

Reality is now experienced through a hyper-connected world with an enormous abundance of data spanning news, advertisements and opinions. The Internet and the virtural communitiies have established a universe in which everybody may serve as a source of information, as opinion leaders and potential influencers (Brown and Fiorella, 2013; Halvorsen et al., 2013).

Hence, influence marketing correspondingly stems from the convergence of different sources of knowledge and practices such as word-of-mouth, digital marketing, social marketing or even neuromarketing. This studies the social dynamics of a particular community, identifies those with influence in these environments before designing and developing platforms for the dissemination of stories and constantly measuring the results throughout the entire process with the objective of altering consumption habits and the perception of the values of brands, products or services. 
Thus is very commum to associate the concept of influence marketing to social media tools. These communication instruments inlude a wide set of online tools and technologies, as such the blogs, chat rooms, discussion foruns, service ratings websites, internet discussion boards, moblogs and social networking websites (Ngai et al., 2015).

Up until a certain time, influence marketing practices were thus relatively simple and direct. However, the appearance of the Internet and social network broke up the direct channel of communication between the brand, the influencers and their followers. With virtural communities then fostering and encouraging the exchange of information and opinions, all their users have become influencial. Therefore, to marketeers, ascertaining just which influencers are appropriate to each brand and type of campaign and, subsequently, just which strategy to adopt have become the crucial questions (Brown and Fiorella, 2013).

The range of influence marketing essentially extends to bloggers, youtubers and public figures. The effectiveness of each influencer type varies in accordance with the product undergoing communications and the target communities with the blogs currently holding the greatest weighting in the brand dynamics and still remaining, in general terms, a "very feminine" world both in terms of the type of content and the followers. This communication tool not only offers advantages to the users but is also an increasingly important new reality for marketeers that impacts on the definition of their marketing strategies (Gremler et al., 2001).

With the appearance of the Internet and Computer Mediated Communication (CMC), electronic word-of-mouth emerged (eWOM) with bloggers a correspondingly integral part of this universe (Mutum and Wang, 2011). Consequently, the fact of consumers constantly generating and sharing opinions about products on the Internet has meant that eWOM proves substantially faster and wider reaching than traditional word-of-mouth (Han et al., , 2009).

ewOM can be defined as any positive or negative opinion made by the current or previous clients about a product, service or company, which is made available to large audiences through the internet (Abubakar et al., 2016; Hennig-Thurau et al., 2004). ewOM is capable of influencing consumers' attitudes as well as their purchase decisions. Additionally, it is considered very persuasive, which can be partially explained by its perceived credibility and trustworthiness (Chatterjee, 2001). As such, the brands are particularly motivated to understand the ewOM, because the conventional forms of communication appear to be losing its effectiveness (Abubakar et al., 2016).

According to Kulmala (2011) and Gruen et al. (2006), ewOM holds influence over consumers and steadily gaining an increasing level of recognition as a relevant and reliable channel of communication to the consumer. The growth of ewOM has gained in relevance in conjunction with the proliferation of User Generated Content (UGC) created by individuals and disseminated immediately across various Internet platforms both easily and effectively (Christodoulides et al., 2012).

The social platforms existing on the Internet, especially virtual communities, social networks and blogs drive the growth in communications oriented towards socialisation with their content created by the users themselves and remaining accessible to everybody. There is effectively a change in the ways people communicate and interact online with the Internet an increasingly dynamic and social tool (Amaral, 2012). In the case of blogs that constitute the main focus of this research project, they may be defined as a website on which one or more authors regularly 
initiate and engage in discussion on a theme of their choice (Dwyer, 2007). Herring et al. (2004) characterise the blogs as frequently modified and updated web pages in which their entrances follow a reverse chronological sequence. Furthermore, these authors also point to how these blogs enable commentaries on already published content as regards the topic under discussion, thereby enabling conversations between the authors and their readers as well as interactions among the readers themselves.

There is no censorship or editorial limitations apart from those that bloggers might impose on themselves. To this end, the blogosphere emerges as a place of free expression in which individual bloggers hold total autonomy. According to Granieri (2006), blogs "inform but are not journalism as we know it. (...) Just as, while telling stories, blogs do not amount to a literary genre" (2006, p.34).

In summary, these platforms represent a means of online and social interaction in which the users unite in order to share information and opinions about the most diverse subjects (Kaye, 2005).

\section{The influence and contents of fashion and beauty blogs}

According to Ngai et al. (2015), blogs are used by authors aiming to post their writings or information about something of their interest, hoping that someone will read them. At a given time, blogs have become also a social reflection around phenomena related to fashion and beauty due to the scope for any individual to contribute with their opinions not only through access but also free choice and active participation. Simultaneously, blogs may also be considered a source of precious information whether for creatives or for the respective industries (Sedeke, 2012).

The blogging approach to the various subjects making up this universe present new opportunities to the fashion and beauty industries and winning over, through the constant creation and publication of new and original contents, new audiences. Marwick (2011) states how fashion and beauty blogs, through their respective publications, provide publicity for the stylistic image of the respective blogger, the products they utilise, opinions on the mass market or on a particular brand and thereby establishing an alternative to the already existing communication channels. Transversally, these blogs inherently contain a greater appeal for interaction, the exchange of ideas and eventually consumer needs and therefore considered as if "street fashion, a source of public opinion" (Sedeke, 2012, p. 2).

The vast majority of bloggers are consumers of fashion and beauty and loyally accompany developments in the industry. We may thus state that the bloggers are simultaneously content consumers and creators, participating in "the global flow of consumption through the purchase of goods (clothing, footwear, accessories, makeup, etcetera), writing posts and sharing photographs that foster fashion as a concept" (Marwick, 2011, p. 2).

In the feminine universe and in the world of fashion and beauty, consulting blogs proves significantly popular in keeping with how women increasingly need to obtain information and opinions from "real" people as regards the brands and products that they deem important and "emotional" such as: clothing, accessories, cosmetics and makeup. As a rule, consumers tend to consider the motivations driving this sharing by bloggers not to be commercial and to the contrary of the brand 
marketeers and advertisers (Bickart and Schindler, 2001; Wolfinbarger and Gilly, 2001). This platform thus becomes a credible source of information about products and trends in the field of fashion and beauty and thus verifying a gradual rise in the numbers of women making recourse to blogs to find inspiration and remain in-fashion (Kulmala, 2011).

According to Brown and Fiorella (2013), after the brand identifies a specific target audience for a particular campaign, the next step is to activate the appropriate "influencer" for conveying such a message. This is the key factor in the success or otherwise of campaigns and, when neglected converts into the reason many campaigns that turn to online communication platforms do not obtain favourable financial returns as regards their campaign investments. The influencer may have been chosen based upon a generic topic and led into the sharing of messages that do not contain any personal connection. The same authors refer to how the brand should identify someone in possession of a genuine and real bond with the topic and who may express themselves with authority on the issue and within a relevant context to their platform. Influence marketing therefore does not only involve getting the largest number of followers or the highest level of interaction but also in making the consumer an influencer, identifying the context that leads to their purchasing decisions. Thus, according to Abubakar et al. (2016), purchase intention is influenced not only by the product value and benefits, but also by testimonies from other consumers.

Taking into account the particularities of blogs and purchasing intentions, we formulated the following research hypothesis:

H1: There are significant difference between individuals who intend and those who do not intend to buy the products presented when taking into account their attitudes towards the blogs followed.

Partnerships between brands and blogs are increasingly common given that the former believe that this means of promotion is both solid and able to generate returns and provding benefits to both of the parties involved (Kim and Jim, 2006). Currently, fashion and beauty brands are undertaking specific strategies and programs for bloggers.

Halvorsen et al. (2013) refer to some of the techniques applied by brands. For example, paid posts (monetary incentives to bloggers to generate ewOM and share posts about their products); affiliation programs (programs that brands in the fashion and beauty areas establish with in partnership with opinion leaders with returns for both parties); brand publicity banners; the gifting of products to bloggers (clothing, makeup, accessories); bloggers as brand representatives; securing their presence at events and competitions; and the review systems and blogs run by the brands themselves (online commentaries and recommendations).

Thus, as regards the bloggers, there is the following hypothesis:

$\mathrm{H} 2$ : There are significant differences between the individuals who intend and those who do not intend to buy the products presented when taking into consideration their opinion in relation to bloggers.

In fashion and beauty blogs, the contents posted interrelate usually with everything belonging to the feminine universe and of personal interest to the authors of this same type of blog, including for example trends in fashion, makeup, cosmetics, healthcare, diet, and among others. These blogs 
may also contain thoughts, opinions, experiences and visual contents (Rickman and Cosenza, 2007).

Thomas et al. (2007) and Kulmala (2011) carried out specific analysis on the content most frequently found associated with the themes of fashion and beauty. In these studies, the most popular themes encapsulate approaches to style, trends, brands, shopping, and product reviews. We now move on to detailing some of these content types.

Chen and Xie (2008) state that online reviews or information about products published in blogs and created by consumers represent a new channel of communication and ewOM of the greatest importance. These reviews thus increasingly take on an important role in purchasing decisions and hence constituting one source of major influence over the sale of products. Consumers consult the reviews of other consumers in order to obtain more information about the products they are interested in. Also according to Chen and Xie (2008), these reviews are, as a rule, fairly informative and containing two types of information that mutually interact: information on the product supplied by the brand and the information generated by the consumer. Generally, the bloggers present the product in accordance with the information made available by the brand and then subsequently express their own personal opinion about it.

Therefore, we arrive at our third hypothesis:

H3: There are significant differences between the individuals that intend to purchase and those who do not intend to purchase the products presented whenever this takes into account their attitude to the reviews seen.

Visual content including the illustrations of personal outfits represents another of the more common themes on fashion and beauty blogs. Thomas et al. (2007) refer to how each blogger has a unique personal style and hence topics surrounding such personal styles are fairly common on these blogs. In this type of posts, the bloggers share their personal styles and preferences with their followers and hence becoming deemed as true opinion leaders as regards fashion and style. Generally, at the end of the post, they also provide useful information to the readers who seek to acquire whatever has been featured (brand, price, etc.). Indeed, many followers are influenced to such an extent by bloggers that they openly seek to imitate their styles and outfits (Kulmala, 2011).

Thomas et al. (2007) state that "trend" related posts essentially share the latest trends in the world of female fashion approaching not only fashion but also interrelated themes such as makeup, hair and accessories and, on occasion, the actual opinions of bloggers. This also commonly deploys images selected from a diverse range of sources in order to represent the new trend. These posts inspire their followers and ensure that they feel encouraged to express their own opinions as regards the respective trend in question (Kulmala, 2011).

In some cases, as an alternative to posts in text and photograph formats, there are bloggers that turn to Youtube to share videos with themes such as "Purchases and products received", given that this alternative channel enables greater ease in presenting and learning the product characteristics. Similarly, there are also many followers requesting, through the comments section, that bloggers use the products so that they are able to see the final result (Kulmala et al., 2013).

Currently, fashion and beauty blogs extend beyond talk about the trends in fashion and beauty products. There is an increasing and deepening effort to diversity the themes approached thus 
establishing a broader reaching category, vey often designated as "lifestyle". This correspondingly also reflects in the sharing of some of the personal moments of bloggers that then results in closer relationships with their followers (Mcquarrie et al., 2013).

\section{Fashion and beauty consumer behaviours}

According to Solomon and Ralbot (2004), the influence of social communiteis in the spread of new fashions and trends gains broad recognition. From the outset, analysing factors such as opinion leading, looking for opinions and the uniqueness of the consumer not only contributes to a better theoretical understanding of these phenomena but also focuses attention on studying the practical implications for brands and the companies in which marketing professionals seek to influence attitudes and behaviours (Elliot, 1994; Goldsmith and Clark, 2008).

In relation to fashion leaders, these may be defined as those persons demonstrating greatest interest in the areas of fashion relative to other consumers in the market, displaying greater trust in their own tastes and choices, buying the new fashions and, above all, influencing other consumers as regards adopting new styles and purchasing new pieces of clothing (Kaiser, 1990; Greenberg et al., 1982; Polegato and Wall, 1980; Schrank and Guilmore, 1973).

Currently, bloggers are considered opinion leaders given that they wield immense influence over the opinions of other consumers. Hence, brands are increasingly turning their attention to the credibility of the respective blog, its predominant themes and the numbers and genres of readers as critical factors in the choice of them for showing off their products within the scope of obtaining advantages for both parties (Carrera, 2009).

In the case of the followers in the areas of fashion and beauty, those who seek out opinions take on particular importance given they act in accordance with the information they receive from bloggers (following modes and trends) and may in fact themselves turn into opinion leaders through once again sharing the same information that they obtained from the opinion leaders (Goldsmith and Clark, 2008).

Solomon (2010) reports that influence is as driven by the influencers as it is by the interactions among those receiving such influence. In being involved in a type of product and constantly seeking information, they dialogue and elicit opinions among themselves, in addition to with the respective opinion leader, as a member of a network of influences.

In turn, Bertrandias and Goldsmith (2006) point to how some studies conclude in favour of the existence of positive correlations between opinon leaders and the search for opinions across different categories of products. However, there is little understanding of the actual motivations and degree of engament of those doing the searching beyond their simple needs to obtain information (Barger et al., 2016). In the case of fashion and beauty blogs, those searching opinons are less involved in the product categories than those who rank as the opinion leaders but who nevertheless still wish to take the very best decisions due to the potential social implications arising (Goldsmith and Clark, 2008). Correspondingly, Huang, Chou and Lin (2008) mention four core motivations for following opinion leaders and accessing their blogs: the interpersonal exchange and discussion of opinions, the search for information, entertainment and following trends. 
Goldsmith and Clark (2008) confirm how, within a context of consumerism, individuals seeks to avoid compliance with the established social norms, avoiding similarities and displaying the tendency to select products and brands that enable them to stand out from others in society and thereby boosting their position and self-image. Many of these individuals feel the need to express their singularity through the notable behaviours that foster observable differences (Workman and Kidd, 2000).

Hence, and correspondingly, we may formulate the following hypothesis:

H4: the motivation of followers to seek out information on blogs interrelates with their need for self-affirmation.

\section{Methodology}

We developed a descriptive and transversal study, quantitative in type, with the objective of identifying the importance that influence marketing currently assumes within the scope of fashion and beauty blogs. To this end, we carried out a questionnaire survey with the target audience composed of the followers of the various fashion and beauty blogs. Through this questionnaire, we sought to capture and analyse fashion and beauty blog related phenomena and their respective influence on the behaviours of followers; to understand the ways in fashion and beauty blogs get used as research and information platforms; to gain insights into the relationships between bloggers and the purchasing decisions of their followers and, still furthermore, in this way verify the existence of changes in the behaviours and choices relative to the consumer's own style of fashion as motivated by the blogosphere.

The data gathering took place via the on-line Google Forms platform, where we drafted a questionnaire survey with a first version of this questionnaire applied as a pre-test. The final version was distributed via social networks such as Facebook, Blogger and Wordpress. Through private messages, we requested the cooperation of some bloggers through the sharing of the survey on their Facebook pages and respective blogs.

The body of the questionnaire divided into three sections: the first directly related with the fashion and beauty blogs (such as how they learned of them, motivations, regularity of visits, preferred blogs, characteristics of the blogs and their bloggers); secondly, approaching the attitudes and behaviours of consumers (attitude towards sponsored publications, towards purchasing, factors influencing the relationship with the blog/blogger, personal behaviours, choice and personal style and relationship with fashion) and finally, the sociodemographic details of participants.

Some of the questions orienting this research were adapted from authors such as Huang, Chou and Lin (2008), that mention the main motivation for consumers as following an opinion leader; Halvorsen et al. (2013) who refer to the techniques deployed by brands in their relationships with blogss; Kim and Jim (2006) who focus on the strategies and programs developed by brands specifically for blogs; Kulmala (2011) who draws inspiration from the contents that are most frequently associated with fashion and beauty blogs; and, finally, Goldsmith and Clark (2008) who provide the basis for formulating the questions related to opinion leadership, seeking out opinions and the uniqueness of consumers. 
The respondent sample totalled 424 before verifying through a question filter that only 362 were effectively followers of fashion and beauty blogs. The majority of questionnaire respondents were female in gender $(96.7 \%)$ with ages ranging between 16 and 45 with the greatest prevalence in the 19 to 24 age group (46.4\%) and those aged between 25 and 30 (27.3\%); in the majority graduates $(46.1 \%)$ or having completed secondary school (38.1\%).

After having carried out data collection, we then proceeded with the statistical analysis and interpretation stages undertaken through recourse to SPSS 23 software.

\section{Results: analysis and discussion}

When questioned about the main motivations for following fashion and beauty blogs, the respondents overwhelmingly highlighted "to be up with the trends" (86.2\%), "seeking information about products" $(79.8 \%)$ and as well as "discovering new products" $(32.3 \%)$. These results are in accordance with a study about the motivations for following blogs carried out by Huang, Chou and Lin (2008), whose respondents also pointed to seeking out information, entertainment and following the trends.

As regards the themes attracting the greatest interest when consulting the blogs, these featured the trends $(86.4 \%)$, product reviews $(76.8 \%)$ and personal style and outfits $(73.6 \%)$. On the other hand, among the least chosen themes are meeting at events, competitions and partnerships (4.6\%) and shopping and products received (9\%). Both Thomas et al. (2007) and Kulmala (2011) conclude in their studies that among content and posts, what gets most consulted are: style, trends, brands, shopping and product reviews.

Moving onto testing the hypotheses, in relation to the first formulated hypothesis (H1: There are significant differences between individuals that intend to buy and those that do not intend to buy the products presented when taking into consideration their attitude towards the blogs followed), we present below the mean and the Mann-Whitney $U$ test results with a level of significance of 0.05 (table 1). 
Table 1. Attitude towards blogs versus intentions to buy

\begin{tabular}{llll} 
Attitude towards blogs & $\begin{array}{l}\text { Intention to buy the } \\
\text { product presented }\end{array}$ & $\begin{array}{l}\text { Mean } \\
\text { Rank }\end{array}$ & $\begin{array}{l}\text { Mann-Whitney } \\
\text { U Test }\end{array}$ \\
\hline $\begin{array}{llll}\text { The fashion and beauty blogs } \\
\text { that I follow are objective }\end{array}$ & $\begin{array}{l}\text { I do not intend to buy } \\
\text { I'm considering buying }\end{array}$ & 147.92 & 3660.000 \\
\hline The fashion and beauty blogs & I do not intend to buy & 132.99 & Sig. (0.001) \\
that I follow are accessible & I'm considering buying & 145.06 & Sig. (0.186) \\
\hline The fashion and beauty blogs & I do not intend to buy & 90.88 & 2659.500 \\
that I follow are credible & I'm considering buying & 151.32 & Sig. (0.000) \\
\hline The fashion and beauty blogs & I do not intend to buy & 111.00 & 3404.000 \\
that I follow are useful & I'm considering buying & 148.33 & Sig. (0.003) \\
\hline The fashion and beauty blogs & I do not intend to buy & 114.50 & 3533.500 \\
that I follow have quality & I'm considering buying & 147.25 & Sig. (0.009) \\
\hline The fashion and beauty blogs & I do not intend to buy & 134.41 & 4270.000 \\
that I follow are appealing & I'm considering buying & 144.28 & Sig. (0.355) \\
\hline The fashion and beauty blogs & I do not intend to buy & 120.88 & 3769.500 \\
that I follow are involving & I'm considering buying & 146.86 & Sig. (0.024) \\
\hline
\end{tabular}

As may be seen, through analysis of the mean classification results, whenever there is a favourable opinion in relation to the blogs, there is a greater predisposition to purchase the products presented. However, there are no significant difference between the two groups of individuals as regards accessibility $(\mathrm{p}=0.186)$ and whether or not the blog is appealing $(\mathrm{p}=0.355)$. As in the other cases, there are significant differences between the groups $(\mathrm{p}<0.05)$ and we correspondingly opted not to reject the formulated hypothesis.

According to Hauge (2007), communicating with consumers that something is in fashion simply through traditional mass marketing no longer functions as the blogs have currently got a significant number of followers and they prove expressive, genuine and representing a source of inspiration now with an enormous impact (Sedeke, 2012).

Furthermore, Armstrong and McAdams (2011) emphasise the relevance of having information available to all those potentially interested in following the blog. In turn, the credibility, according to Kulmala (2011), undergoes strengthening due to the relationship of "friendship" established between bloggers and followers that mutually share opinons and advice as regards the themes prevailing in the area. In relation to the quality, Mcquarrie et al. (2013) affirm how followers prefer posts in the "personal style" that convey some care as regards content quality, especially as regards the photographs, videos and texts, that should reflect a tended to and professional appearance.

In relation to the second hypothesis $(\mathrm{H} 2)$ : There are significant differences between the individuals who intend and those who do not intend to purchase the products presented when taking into consideration their opinion in relation to bloggers), we set out below the results of the means and the Mann-Whitney $\mathrm{U}$ test for a significance level of 0.05 (table 2). 
Table 2. Attitude towards bloggers versus intention to buy

\begin{tabular}{llll} 
Attitude regarding the bloggers & $\begin{array}{l}\text { Intention to buy the } \\
\text { product presented }\end{array}$ & $\begin{array}{l}\text { Mean } \\
\text { Rank }\end{array}$ & $\begin{array}{l}\text { Mann-Whitney } \\
\text { U Test }\end{array}$ \\
\hline They convey precise information & I do not intend to buy & 100.58 & 3018.500 \\
& I'm considering buying & 149.33 & Sig. (0.000) \\
\hline They demonstrate high levels of & I do not intend to buy & 116.76 & 3617.000 \\
knowledge in their postings & I'm considering buying & 146.92 & Sig. (0.009) \\
\hline I believe their recommendations are true & I do not intend to buy & 94.70 & 2801.000 \\
& I'm considering buying & 149.66 & Sig. (0.000) \\
\hline They are credible & I do not intend to buy & 88.69 & 2578.500 \\
& I'm considering buying & 151.64 & Sig. (0.000) \\
\hline They are biased (R) & I do not intend to buy & 143.60 & 4460.500 \\
(R) - Reverse question & I'm considering buying & 142.91 & Sig. (0.952) \\
\hline
\end{tabular}

Through analysis of the mean results, we may state that whenever there is a favourable opinion in relation to the bloggers, there is a greater predisposition to buy the products presented. However, there are no significant differences between the two groups of individuals as regards the "are biased" ( $p=0.952)$ item. Hence, given that there are significant differences existing between the groups $(\mathrm{p}<0.05)$, we do not reject the formulated hypothesis.

In keeping with these results, Svensson (2011) maintains that consumers tend to trust in "genuine" and personal accounts more than in marketeers and advertisers. Within the fashion and beauty universe, women increasingly seek out information and opinions from "real" persons as regards the products and brands to their interest and liking. Thus, consumers consider that the motivation for sharing held by the bloggers is not commercial contrary to that of the marketeers and advertisers of brands (Bickart and Schindler, 2001; Wolfinbarger and Gilly, 2001).

Complementarily, we questioned respondents as regards the factors that most contribute, in their perspective, towards bloggers getting ranked as the new opinion leaders. A majority of individuals (60.7\%) considered that this stemmed from how they wield immense influence in the opinion of consumers and immediately afterwards followed by the $16.9 \%$ who believe that this emerges from the powerful influence they exert over buying behaviours. In fact, Carrera (2009) adds that bloggers may be considered opinion leaders as they hold immense influence over the opinions of other consumers before also affirming that "certain persons" become opinion leaders in keeping with their capacity to operate as distributors on the social networks and with the power of their influence receiving widespread recognition. Furthermore, Ryan and Jones (2009) state that opinion leaders present characteristics such as: being considered as specialists in particular areas, in possession of a very wide social circle and a stong online presence and cultivating interactions with their followers.

As regards our third hypothesis (H3): There are significant differences between the individuals that intend to purchase and those who do not intend to purchase the products presented whenever this takes into account their attitude to the reviews seen, the table below displays the mean and the Mann-Whitney U test results for a 0.05 level of significance (table 3). 
Arminda Paço \& Sofia Oliveira

Table 3. Attitude towards the reviews versus buying intention

\begin{tabular}{llll} 
Attitude towards the reviews & $\begin{array}{l}\text { Intention to buy the } \\
\text { product presented }\end{array}$ & $\begin{array}{l}\text { Mean } \\
\text { Rank }\end{array}$ & $\begin{array}{l}\text { Mann-Whitney } \\
\text { U Test }\end{array}$ \\
\hline $\begin{array}{l}\text { These publications reflect genuine and true opi- } \\
\text { nions }\end{array}$ & I do not intend to buy & 74.88 & 2067.500 \\
& I'm considering buying & 153.70 & Sig. (0.000) \\
\hline $\begin{array}{l}\text { These publications are useful because I am able } \\
\text { to get good information }\end{array}$ & I do not intend to buy & 69.19 & 1857.000 \\
& I'm considering buying & 154.54 & Sig. (0.000) \\
\hline $\begin{array}{l}\text { I was precisely informed about the product's } \\
\text { characteristics }\end{array}$ & I do not intend to buy & 76.54 & 2129.000 \\
& I'm considering buying & 153.45 & Sig. (0.000) \\
\hline $\begin{array}{l}\text { I do not normally believe in the content of these } \\
\text { reviews (R) }\end{array}$ & I do not intend to buy & 81.00 & 2294.000 \\
\begin{tabular}{l} 
(R) - Reverse question \\
\hline
\end{tabular} & I'm considering buying & 152.79 & Sig. (0.000) \\
\hline
\end{tabular}

Following analysis of the mean classification results, we would note the significant differences in all the groups of individuals $(\mathrm{p}<0.05)$; whenever there is a positive attitude in relation to the reviews seen, there is greater motivation towards buying and therefore confirming the formulated hypothesis. These results align with the description by Chen and Xie (2008) that identifies how information arriving from other consumers proves highly influential over consumer purchasing decisions. According to Kulmala (2011), even when the actual purchase does not take place, there remains the desire and curiosity over discovering the product in the future.

However, we should nevertheless stress how controversy continues to surround paid posts as followers do not immediately recognise commercial messages in the blog contents. There is a need for blogging to remains as transparent as is feasible with bloggers correspondingly revealing the campaigns and brands associated with their posts (Kulmala, 2011).

Hypothesis 4 seeks to ascertain whether there is any relationship between the motivation to look for information on blogs and the need to affirm a particular style. In order to obtain the correlation between the variables, we extracted the Spearman Rank Correlation Coefficient (p) to a 0.05 level of significance (table 4). 
Table 4. Correlation coefficient between the search for information and the seeking of affirmation

\begin{tabular}{|c|c|c|c|}
\hline $\begin{array}{l}\text { Search for information Search } \\
\text { for affirmation }\end{array}$ & $\begin{array}{l}\text { Correlation } \\
\text { Coefficient }\end{array}$ & $\begin{array}{l}\text { I'm involved in the area and } \\
\text { constantly seek information }\end{array}$ & $\begin{array}{l}\text { I want to be up with } \\
\text { the latest trends }\end{array}$ \\
\hline \multirow{3}{*}{$\begin{array}{l}\text { I avoid complying with the socially es- } \\
\text { tablished norms (fashion and beauty) }\end{array}$} & $\mathrm{p}$ & 0.548 & 0.664 \\
\hline & Sig. & 0.000 & 0.000 \\
\hline & $\mathrm{N}$ & 359 & 360 \\
\hline \multirow[t]{3}{*}{ I feel the need to express my singularity } & $\mathrm{p}$ & 0.532 & 0.606 \\
\hline & Sig. & 0.000 & 0.000 \\
\hline & $\mathrm{N}$ & 359 & 360 \\
\hline \multirow{3}{*}{$\begin{array}{l}\text { I avoid similarities and seek out items } \\
\text { and brands that stand out }\end{array}$} & $\mathrm{p}$ & 0.506 & 0.589 \\
\hline & Sig. & 0.000 & 0.000 \\
\hline & $\mathrm{N}$ & 359 & 360 \\
\hline \multirow{3}{*}{$\begin{array}{l}\text { I consider fashion as a form of expres- } \\
\text { sion }\end{array}$} & $\mathrm{p}$ & 0.345 & 0.483 \\
\hline & Sig. & 0.000 & 0.000 \\
\hline & $\mathrm{N}$ & 359 & 361 \\
\hline
\end{tabular}

As this coefficient varies between -1 and 1 , we may correspondingly state that all these relationships attain significance $(\mathrm{p}=0.000)$ and that there is a moderate association among the variables given that their results range from 0.3 and 0.7 . The most robust relationships are "I want to be up with the latest trends"/"I avoid complying with the socially established norms" ( $p=0.664)$, and "I want to be up with the latest trends"/"I feel the need to express my singularity" ( $p=0.606)$. We may therefore confirm $\mathrm{H} 4$ : the motivation of followers to seek out information on blogs interrelates with their need for self-affirmation.

Bertrandias and Goldsmith (2006) affirm that seeking out opinions/information is directly related with a certain type of consumer behaviour, that is, describes the influence of other persons and factors and the need for exclusivity experienced by some buyers. Goldsmith and Clark (2008) confirm how individuals avoid similarities and tend to select products and brands that strengthen their individual positioning and self-image.

The results returned align with the findings of Goldsmith and Clark (2008) who state that in a context of consumption, those individuals who avoid complying with the social norms also avoid similarities and tend to select products and brands that enable differentiation from others in society. Being "in fashion" and being unique are thus considered forms of expression (Elliot, 1994).

\section{Conclusion}

The main objective of the present study consists of identifying the importance that influence marketing holds in fashion and beauty blogs. Hence, this strives to grasp how the fashion and 
beauty blogs influence the consumer/follower and which factors might interrelate with this impact. In general terms, we may state that influence marketing does impact on purchasing intentions as regards the products presented as well as on attitudes and behaviours towards fashion and beauty.

We also verify how influence marketing constitutes an increasing presence in fashion and beauty blogs and, through them and their "influencers" -the bloggers - companies and brands have constructed a new scenario for fashion and beauty in the online world and correspondingly involving the influential blogs in their communication strategies.

These communications strategies, based on influence marketing, applied by brands through their presence in blogs, reflect a change in paradigm that now rests upon new practices for interacting with the public alongside the adoption of new forms of communication such as ewOM about brands and products with the specific objective of shifting consumption habits and deployed in the form of real endorsments and genuine dialogues between influencers/ opinion leaders and consumers.

As regards the influence marketing present in blogs and the consumer/follower intentions to buy, we may report that the opinions and attitudes as regards the blogs and the respective bloggers, as opinion leaders as well as in their relationships with the contents, such as the reviews, gain a high level of importance in consumer behaviours and purchasing intentions. When there is a favourable opinion as regards these factors, there is a greater predisposition towards purchasing the products. Influence marketing fosters genuine and true communications with consumers tending to trust in the "real" information and opinions of the blogs and their bloggers with which they identify.

In general terms, we may also report that consumers hold favourable opinions towards blogs, irrespective of the age group, with the majority openly accepting that they identify and relate to the bloggers and their blogs. We also verified that there is a higher frequency of accessing blogs among the older respondents in our sample (31-36 and aged over 36) and that their motivations to follow these blogs stem from wishing to keep up with the trends and seeking out information on products and, as regards their specific interests, they identify trends, product "reviews" and as well as personal styles and outfits.

As regards the behaviours involved in buying/the choices and personal styles of consumers, they convey how they feel the need to express their singularity and totally agree that fashion constitutes a form of self-expression. The majority of blog followers confirm that they draw inspiration from the outfits and personal styles of the bloggers, nevertheless, while attempting to themselves be innovative. We may correspondingly conclude that the search for affirmation and the need to express singularity interrelate with the search for information in blogs and that, in a certain fashion, this verifies the influence of the bloggers, their styles and opinions, over consumers.

In relation to the research hypotheses formulated, we thus conclude that whenever there is a favourable opinion towards the blogs, the bloggers and their reviews, there is also a greater predisposition towards the purchase of the products presented. We may also confirm how consumers openly accept that they are seeking information out of a desire to remain updated about the latest fashions and avoiding complying with the socially established norms.

We consider that analysis of the research results of this article proves significantly valuable to companies and brands engaged in the areas of fashion and beauty, as well as marketeers and adver- 
tisers more generally, in keeping with the rising interest of various organisations in collaborating with blogs due to their capacity to wield influence both at the level of the images consumers hold towards brands as well as in terms of their behaviours and purchasing intentions. Hence, strategies requires re-thinking with marketing developing in accordance with real stories around the brand that integrate the influencers as elicitors of emotions so as to persuade consumers to buy and/or spread opinions about the products/services.

Additionally an understanding of the psychology linking social media use to consumption can help managers in developing marketing strategies to promote the buying of certain goods.

As happens with all research projects, these findings are not exempt from limitations. Thus, the first limitation, perceived at the outset of the research, derives from the shortcomings in the specific and scientific literature on influence marketing, especially as an only relatively recent concept. We also encounter a corresponding scarcity of studies on fashion and beauty blogs and their impacts on consumer behaviours.

Another limitation arises from the scale of the sample that served as the basis for this study, which might be both broader and more diversified. Furthermore, we might have made recourse to other data collection techniques, such as interviews with bloggers and companies adopting this form of marketing, in order to ensure a more complete study.

Future research might make a more detailed approach to the potential implications of this phenomenon (blogging) for brands as well as deeper reaching study of the partnerships between bloggers and brands and the added value resulting for both parties, of the marketing strategies necessary for a blog to become successful, and/or comparative analysis of fashion and beauty blogs at the international level.

\section{References}

Abubakar, M.; Ilkan, M. \& Sahin, P. (2016). ewom, eReferral and gender in the virtual community. Marketing Intelligence \& Planning, 34 (5): 692-710.

Amaral, I. (2012). Participação em rede: do utilizador ao consumidor 2.0 e ao prosumer. Сотиnicação e Sociedade, 22: 131-147.

Armstrong, C. L. \& McAdams, M.J. (2011). Blogging the time away? Young adults' motivations for blog use. Atlantic Journal of Communication, 19 (2): 113-128.

Barger, V.; Peltier, J. \& Schultz, D. (2016). Social media and consumer engagement: a review and research agenda. Journal of Research in Interactive Marketing, 10 (4): 268-287.

Bertrandias, L. \& Goldsmith, R. E. (2006). Some psychological motivations for fashion opinion leadership and fashion opinion seeking. Journal of Fashion Marketing and Management, 10 (1): $25-40$.

Bickart, B. \& Schindler, R. M. (2001). Internet forums as influential sources of consumer information. Journal of Interactive Marketing, 15 (3): 31-40.

Brown, D. \& Fiorella, S. (2013). Influence marketing. Indianapolis: Que Publishing.

Carrera, F. (2009). Marketing digital na versão 2.0. Lisboa: Edições Sílabo. 
Chatterjee, P. (2001). Online reviews: do consumers use them?. Advances in Consumer Research, 28 (1): $129-133$.

Chen, Y. \& Xie, J. (2008). Online consumer review: word-of-mouth as a new element of marketing communication mix. Management Science, 54 (3): 477-491.

Christodoulides, G.; Michaelidou, N. \& Argyriou, E. (2012). Cross-national differences in e-WOM influence. European Journal of Marketing, 46 (11/13): 1689-1707.

Dwyer, P. (2007). Measuring the value of electronic word-of-mouth and its impact in consumer communities. Journal of Interactive Marketing, 21 (2): 63-79.

Elliott, R. (1994). Exploring the symbolic mean of brands. Bristish Journal of Management, 5: S13-S19.

Goldsmith, R. E. \& Clark, R. A. (2008). An analysis of factors affecting fashion opinion leadership and fashion opinion seeking. Journal of Fashion Marketing and Management, 12 (3): 308322.

Granieri, G. (2006). Geração Blogue, Lisboa: Editorial Presença.

Greenberg, B. A.; Lumpkin, J. R. \& Bruner, G. C. (1982). Opinion leadership and innovativeness in fashion diffusion. Proceedings of Annual Meeting of the American Institute for Decision Sciences (pp. 240-242). American Institute for Decision Sciences, Atlanta, Ga, USA.

Gremler, D. D.; Gwinner, K. P. \& Brown, S. W. (2001). Generating positive word-of- mouth communication through customer-employee relationships. International Journal of Service Industry Management, 13 (1): 44-59.

Gruen, T. W.; Osmonbekov, T. \& Czaplewski, A. J. (2006). ewOM: the impact of customer-tocustomer online know-how exchange on customer value and loyalty. Journal of Business Research, 59 (4): 449-456.

Halvorsen, K.; Hoffmann, J.; Coste-Manière, I. \& Stankeviciute, R. (2013). Can fashion blogs function as a marketing tool to influence consumer behavior? Evidence from Norway. Journal of Global Fashion Marketing, 4 (3): 211-224.

Han, M.; Jang, Y. \& Park, H. (2009). Bloggers' intrinsic motivation and electronic word- of-mouth marketing. Working Paper, Korea Advanced Institute of Science and Technology.

Hauge, A. (2007). Dedicated followers of fashion. An economic geographic analysis of the. swedish fashion industry. Doctoral thesis. Uppsala University.

Hennig-Thurau, T.; Gwinner, K. P.; Walsh, G. \& Gremler, D. D. (2004). Electronic word- ofmouth via consumer-opinion platforms: what motivates consumers to articulate themselves on the internet?. Journal of Interactive Marketing, 18 (1): 38-52.

Hennig-Thurau, T.; Gwinner, K. P.; Walsh, G. \& Gremler, D. D. (2004). Electronic word-of-mouth via consumer-opinion platforms: what motivates consumers to articulate themselves on the internet. Journal of Interactive Marketing, 18 (1): 38-52.

Herring, S. C.; Scheidt, L. A.; Bonus, S. \& Wright, E. (2004). Bridging the gap: A genre analysis of weblogs. Proceedings of the $37^{\text {th }}$ Hawaii International Conference on System Sciences: $1-11$. 
Huang, C. Y.; Shen, Y. Z.; Lin, H. X. \& Chang, S. S. (2007). Bloggers' motivations and behaviors: a model. Journal of Advertising Research, 47 (4): 472-484.

Hudson, S.; Roth, M.; Madden, T. \& Hudson, R. (2015). The effects of social media on emotions, brand relationship quality, and word of mouth: An empirical study of music festival attendees. Tourism Management, 47: 68-76.

Kaiser, S. B. (1990). The Social Psychology of Apparel. $2^{\text {nd }}$ Edition, New York: Macmillan.

Kaye, B. K. (2005). It's a blog, blog, blog, blog world. Atlantic Journal of Communication, 13 (2): 73-95.

Kim, H. \& Jin, B. (2006). Exploratory study of virtual communities of apparel retailers. Journal of Fashion Marketing and Management, 10 (1): 41-55.

Kulmala, M. (2011). Electronic Word-of-Mouth in Consumer Fashion Blogs. Master thesis, School of Management, University of Tampere.

Kulmala, M.; Mesiranta, N. \& Tuominen, P. (2013). Organic and amplified ewOM in consumer fashion blogs. Journal of Fashion Marketing and Management, 17 (1): 20-37.

Marwick, A. (2011). Conspicuous and authentic: fashion blogs, style and consumption. Retrieved October 20, 2016, from www.tiara.org/papers/amarwick_conspicuousauthentic.pdf.

Mcquarrie, E. F.; Miller, J. \& Philips, B. J. (2013). ewOM the megaphone effect. Taste and audience in fashion blogging. Journal of Consumer Research, 40 (1): 136-158.

Mutum, D. \& Wang, Q. (2011). Handbook of research on digital media and advertising: user generated content consumption. UK: University of Warwick.

Ngai, E.; Moon. K.; Lam, S.; Kee, L.; Chin, E. \& Tao, S. (2015). Social media models, technologies, and applications. An academic review and case study. Industrial Management \& Data Systems, 115 (5): 769-802.

Polegato, R. \& Wall, M. (1980). Information seeking by fashion opinion leaders and followers. Home Economics Research Journal, 8 (5): 327-338.

Rickman, T. A. \& Cosenza, R. M. (2007). The changing digital dynamics of multichannel marketing: the feasibility of the weblog. Text mining approach for fast fashion trending. Journal of Fashion Marketing and Management, 11 (4): 604-621.

Ryan, D. \& Jones, C. (2009). Understanding digital marketing - marketing strategies for engaging the digital generation. London: Kogan Page.

Schrank, H. L. \& Guilmore, L. (1973). Correlates of fashion leadership: implications for fashion process theory. The Sociological Quartely, 14 (4): 534-543.

Sedeke, K., (2012). Effective fashion blogs and their impact on the current fashion industry. Master thesis, Faculty of History, Communication and Art, Erasmus University Rotterdam

Solomon, M. \& Rabolt, N. (2004). Consumer behavior: in fashion. New Jersey: Prentice Hall.

Solomon, M. R. (2010). Consumer behavior - buying, having and being. UK: Pearson.

Svensson, A. (2011). Facebook - the social newspaper that never sleeps: a study of Facebook eWOM's persuasiveness on receivers. Master degree project, University of Gothenburg. 
Taylor, D. \& Strutton, D. (2016). Does Facebook usage lead to conspicuous consumption? The role of envy, narcissism and self-promotion. Journal of Research in Interactive Marketing, 10 (3): 231-248.

Thomas, J. B.; Peters, C. O. \& Tolson, H. (2007). An exploratory investigation of virtual community MySpace.com: what are consumers saying about fashion?. Journal of Fashion Marketing and Management, 11 (4): 587-603.

Vries, L.; Gensler, S. \& Leeflang, P. (2012). Popularity of brand posts on brand fan pages: an investigation of the effects of social media marketing. Journal of Interactive Marketing, 26: 83-91.

Wolfinbarger, M. \& Gilly, M. (2001). Shopping online for freedom, control, and fun. California Management Review, 43 (2): 34-55.

Workman, J. E. \& Kidd, L. K. (2000). Use of the need for uniqueness scale to characterize fashion consumer groups. Clothing and Textiles Research Journal, 18 (4): 227-236. 